\title{
$\begin{array}{ll}\text { Research Square } & \begin{array}{l}\text { Preprints are preliminary reports that have not undergone peer review. } \\ \text { They should not be considered conclusive, used to inform clinical practice, } \\ \text { or referenced by the media as validated information. }\end{array}\end{array}$
}

\section{Gene Therapy with Hepatocyte Growth Factor Improves Left Ventricular Systolic Function After Myocardial Infarction: A Systematic Review and Meta-analysis of Pig Models}

\author{
Chong Du \\ The First Affiliated Hospital of Nanjing Medical University https://orcid.org/0000-0002-1102-3406 \\ Xiao-Wen Chen \\ First Affiliated Hospital of Nanjing Medical University \\ Ze-Mu Wang \\ First Affiliated Hospital of Nanjing Medical University \\ Hao-Yu Meng \\ First Affiliated Hospital of Nanjing Medical University \\ Ya-Fei Li \\ First Affiliated Hospital of Nanjing Medical University \\ Tian-Wen Wei \\ First Affiliated Hospital of Nanjing Medical University \\ Lian-Sheng Wang ( $\nabla$ drlswang@njmu.edu.cn ) \\ The First Affiliated Hospital of Nanjing Medical University https://orcid.org/0000-0001-8538-6560
}

Research article

Keywords: Hepatocyte growth factor, myocardial infarction, cardiac function, angiogenesis, large animal model, meta-analysis

Posted Date: October 14th, 2020

DOI: https://doi.org/10.21203/rs.3.rs-34290/v2

License: (c) (i) This work is licensed under a Creative Commons Attribution 4.0 International License. Read Full License 


\section{Abstract}

Background: Hepatocyte growth factor (HGF) is an angiogenic cytokine which can promote angiogenesis and inhibit fibrosis. Previous studies have shown that HGF may have significant therapeutic effects on ischaemic diseases, such as ischaemic heart disease and peripheral arterial occlusive disease. Due to insufficient clinical study evidence, we conducted a quantitative meta-analysis of HGF therapy in pigs with myocardial infarction (MI) to provide more reliable evidence for the feasibility and effectiveness of HGF therapy for MI patients. We also analysed the efficacy and characteristics of different gene therapy vectors and drug delivery routes.

Methods: PubMed, EMBASE, and the China National Knowledge Infrastructure were searched for randomised studies that corresponded to our subject. The search terms included (hepatocyte growth factor OR HGF) AND (heart failure OR HF OR myocardial infarction OR MI OR AMI OR coronary heart disease OR CHD). The retrieved articles were screened strictly according to the inclusion criteria. The endpoints were the left ventricular ejection fraction (LVEF) and capillary density in the ischaemic regions in the model pigs.

Results: A total of nine studies were eventually included in this meta-analysis. Our analysis showed that LVEF (with mean difference [MD]:9.73, $95 \% \mathrm{Cl}: 8.70,10.76, P<0.00001)$ and capillary density (MD:79.98, 95\% $\mathrm{Cl}: 24.58,135.39, P=0.005)$ in the HGF group were significantly higher than those in the control group several weeks after HGF treatment. Further analysis showed that there was no statistically significant difference in the improvement of LVEF caused by intracoronary adenovirus ${ }_{5}$-mediated HGF (Ad5-HGF) gene transfer and intramyocardial plasmid HGF injection (12.63 $\pm 3.2 v s 9.4 \pm 1.09, P=0.06$ ), while intramyocardial injection of plasmid HGF had a stronger angiogenic capacity than intramyocardial administration of Ad5-HGF and HGF in hydrogel $(117.34 \pm 27.82$ vs $26.45 \pm 22.11$ vs $11.50 \pm 5.28, P \otimes 0.00001)$.

Conclusions: HGF therapy can effectively promote angiogenesis and recovery of cardiac function and is a promising cardiac repair method. Intracoronary Ad5 vector transfer and intramyocardial injection of plasmid vectors can be used as effective means of gene therapy, and hydrogel as a vector also has potential applications.

\section{Background}

Myocardial infarction (MI), the most severe form of ischaemic heart disease (IHD), causes irreversible apoptosis and necrosis of myocardial cells [1]. The infarcted area is then replaced by fibrous scar tissue, leading to ventricular remodelling and heart failure (HF) [2, 3]. In the process of ventricular remodelling, the oxygen consumption of the hypertrophic ventricular wall increases, the number of capillaries decreases, and the myocardial ischaemia is further aggravated [4,5]. Although early revascularisation can improve blood supply in ischaemic area to a certain extent, cardiac remodelling is still ongoing, resulting in $\mathrm{HF}$ approximately $50 \%$ of the time [6]. The only way to reverse this process is heart transplantation, which is limited by donor organ shortage, high cost, and the need for immunosuppressive medications [7]. Therefore, new therapeutic strategies should be explored for inhibiting cardiac remodelling and improving cardiac repair, and promoting angiogenesis is one promising approach. Among numerous angiogenic strategies, cytokine-based gene therapy has been extensively studied.

At present, a variety of vascular growth factors have been attempted for use in gene therapy after $\mathrm{Ml}$, among which vascular endothelial growth factor (VEGF) and hepatocyte growth factor (HGF) have attracted wide attention [8]. It has been reported that HGF could regulate the expression of cardiomyocyte-specific transcription factors and structural genes through its unique tyrosine kinase receptor, c-Met [9], and then perform functions such as promoting angiogenesis, regulating inflammation, inhibiting fibrosis, and even activating tissue regeneration [10]. HGF, and the activation of c-Met, could alleviate chronic myocardial injury in myocarditis, cardiomyopathy and other disease models [11]. In animal experiments, local HGF administration has been mainly conducted through intracoronary gene transfer using a catheter and intramyocardial injection via thoracotomy [12, 13]. At present, there have been relatively few clinical studies on the local application of HGF for MI treatment which, to some extent, hinders the prospects for application of HGF therapy. In contrast, HGF has been extensively studied in animal models. However, the efficacy of HGF has varied between studies, and researchers have used different carriers and routes of administration. Considering that pigs and humans are relatively similar species, we pooled the preclinical experimental data to provide more reliable evidence for the feasibility of clinical transformation of HGF therapy. In addition, the prospects of different treatment methods were analysed.

This article aims to analyse and summarise the applicability of HGF therapy after MI, as well as to compare and systematically review different approaches, including delivery routes and vehicles, and introduce new ones. Finally, more effective treatment options and future research directions will be discussed.

\section{Methods}

\section{Search strategy}

Two investigators retrieved literature through the PubMed database, the Excerpta Medica Database (Embase), and the China National Knowledge Information database. The search terms used were as follows: (hepatocyte growth factor OR HGF) AND (heart failure OR HF OR myocardial infarction OR MI OR AMI OR coronary heart disease OR CHD). We did not set a starting date for our search, but the end date was set at $28 \mathrm{March}$ 
2020. The publication language was not limited. The retrieved studies were carefully examined to exclude similar articles, and the studies related to the topic in the references of each article were manually retrieved to prevent omissions.

\section{Study selection}

Two investigators independently reviewed all of the retrieved studies, read the full text of each study, including titles and abstracts, and then extracted relevant data. Only randomised studies examining the effect of HGF therapy on cardiac function and angiogenesis in swine models with MI were included. The included studies had to be designed with experimental controls, and article types such as reviews and reports were excluded. Studies were included as long as either LVEF or capillary density was quantitatively assessed.

\section{Quality assessment and data extraction}

Two authors independently assessed the quality of the included studies according to five aspects: randomisation and control, adequate allocation, adequate method of randomisation, blinding of the operator, and blinding of the functional analysis. The following information was extracted from the full text: pig breed, gender, weight, number of pigs, intervention form, follow-up time, and any other relevant information. Any ambiguities were resolved by a more experienced third individual.

\section{Data analysis and statistical methods}

Our primary endpoints were the differences in mean LVEF (\%) and capillary density (capillaries/mm ${ }^{2}$ ) at follow-up between the HGF group and the control group. We also measured the effects of different delivery methods and vehicles on cardiac function and angiogenesis. The mean difference (MD) and 95\% confidence interval (Cl) were used to calculate and assess evaluation data of the continuous results between HGF treatment and control groups. Statistical analysis was performed using Review Manager (version 5.3). Furthermore, $P^{2}$ values were used to assess the heterogeneity among the included articles. If $2 \otimes 50 \%$, the random-effect model would be used; if $2 \otimes 50 \%$, the fixed-effect model would be adopted. To test the robustness of the results, sensitivity analysis was performed by excluding the studies one by one. In addition, we performed subgroup analysis according to different conditions and used funnel plots to describe whether there was potential publication bias.

\section{Results}

\subsection{Search results}

Using the above query method, 1,224 articles were retrieved. We excluded studies that did not address our research topic or did not focus on pigs. Non-controlled studies were also dismissed. We finally included nine studies after excluding similar and identical articles by analysing the full text. The detailed selection process for included studies is represented in Figure 1.

\subsection{Risk of bias assessment and study characteristics}

All nine studies included in the meta-analysis met our selection criteria. The methodological quality of each study was evaluated, and the specific content of the quality assessment is shown in Table 1. In all included studies, MI pig models were established, and were randomly divided into an HGF treatment group and a control group, which conformed to the randomisation and control method. However, not all studies indicated whether blinded analysis of cardiac function and angiogenesis was used. After completing the study quality assessment, we extracted basic characteristics of each study, including pig breed, gender, weight, number of pigs, intervention form, follow-up time, and other relevant information (Table 2). Finally, 115 pigs with MI were analysed, 57 of which received HGF treatment and 58 that received control treatment.

\subsection{Meta-analysis}

Six studies [14-19] provided data on LVEF (\%) and included 81 MI pigs, of which 40 were treated with HGF and 41 were used as controls. Since there was no significant heterogeneity $\left(P^{2}=2 \%, P=0.40\right)$ among studies, the data analysis was based on the fixed-effect model. The results of the analysis suggested that, compared with the control group, local application of HGF significantly increased LVEF (MD:9.73, 95\% Cl:8.70, 10.76, $P$ ]

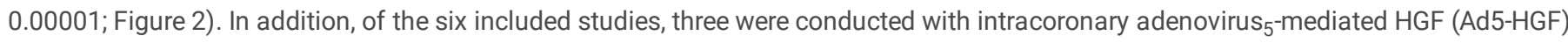
transferred into the myocardium via the right coronary artery, and the other three were conducted with plasmid HGF intramyocardial injection. Therefore, we performed a subgroup analysis based on these two methods, and the results showed that there was no statistically significant difference in the improvement of LVEF between intracoronary injection of Ad5-HGF and intramuscular injection of plasmid HGF (MD: 12.63, 95\% Cl:9.43, 15.83 vs MD:9.40, 95\% Cl:8.31, 10.48, $P=0.06$; Figure 3).

The effects of HGF on angiogenesis in ischaemic areas of MI pigs were studied in five articles $[12,17,18,20,21]$ involving 64 pigs, of which 32 were treated with HGF and 32 were used as controls. Angiogenesis was measured by capillary density (capillaries/mm ${ }^{2}$ ). Considering the significant heterogeneity between studies $(R=98 \% \otimes P<0.00001)$, we used a random-effect model to analyse the difference in capillary density between the HGF group and the control group. The results showed that the capillary density in the ischaemic area of the HGF group was significantly higher than that of the control group (MD:79.98, 95\% Cl:24.58,135.39, $P=0.005$; Figure 4). In addition, an intramyocardial injection

Page 3/11 
delivery method was used in these five studies, but the HGF vehicles used were different. Among them, plasmid vectors were used in three studies, an Ad5 vector in one study, and a hydrogel vector in one study. Therefore, we performed a subgroup analysis to compare the therapeutic effects of different vectors under the same route of administration. The results showed that plasmid-mediated HGF therapy had a stronger angiogenic effect than Ad5 and hydrogel when intramyocardial administration was applied, with a statistically significant difference $(117.34 \pm 27.82$ vs $26.45 \pm 22.11$

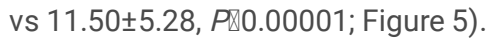

In addition, sensitivity analysis, performed by excluding the studies one by one, demonstrated the same results, which indicated the meta-analysis was robust. However, the funnel plot indicated that there might be some publication bias, as the values were not completely and symmetrically distributed around the overall estimate (Figure 6).

\section{Discussion}

Chronic myocardial ischaemia and ventricular remodelling after MI are important causes of HF. In recent years, gene therapy based on angiogenic factors has become a potential method to promote angiogenesis, inhibit ventricular remodelling, and improve cardiac function [22, 23]. The cytokines that have been studied in preclinical and clinical research include VEGF, HGF, fibroblast growth factor, and insulin-like growth factor, and some studies have achieved encouraging results [24, 25]. Recently, Wang et al. [26] injected adenovirus-mediated VEGF165 into the peri-infarct myocardium in an MI rat heart, and their results suggested that VEGF165 gene therapy could improve cardiac function by inducing angiogenesis and inhibiting cardiomyocyte apoptosis.

HGF and its potential angiogenic, anti-apoptotic, and anti-fibrotic effects [27, 28] have been extensively studied in various models of ischaemic disease, such as MI [29] and peripheral artery occlusion disease [30]. A Phase III clinical trial of intramuscular injection of plasmid HGF for the treatment of severe limb ischaemia has been successful [31], suggesting that HGF may also be used for the treatment of IHD. The biological function of HGF is mediated by its unique tyrosine kinase receptor c-Met [32]. Activation of the c-Met receptor further activates many intracellular signalling pathways, including RAS-mitogen activated protein kinase, signal transducer and activator of transcription, phosphatidylinositol-3 kinase, protein kinase B, mammalian target of rapamycin, and $\beta$-catenin pathway [33, 34]. Our group has previously shown that HGF therapy could promote cardiac repair and improve cardiac function in MI rats through the above mechanisms [35].

Although HGF has been widely studied in some large animal MI models, the clinical trials related to HGF therapy have just started [36], which prompted us to conduct a meta-analysis on the preclinical data. Our study showed that the cardiac pump function of the HGF group was significantly better than that of the control group within 1-2 months after MI, with an increase in LVEF of about $9.73 \%$. In addition to the improvement of LVEF, local application of HGF promoted angiogenesis and increased blood supply to the ischaemic area. Compared with the control group, the capillary density in the HGF treatment group was significantly increased (about 97.33 capillaries/mm² difference). Our study fully demonstrates that HGF treatment after MI can promote angiogenesis and improve the cardiac pump function. Neovascularization can improve the blood supply in ischaemic areas, provide preconditions for the tissue repair of the heart and, to some extent, reverse the fibrosis induced by hypoxia [12].

In terms of vectors and routes of delivery, plasmids, adenoviruses and injectable hydrogels have been widely accepted for gene therapy [37]. As mature and traditional vectors, plasmid- and adenovirus-mediated HGF gene transfer can significantly improve HGF expression in myocardial tissue. Wang et al. [15] transferred Ad5-HGF ( $\left.4 \times 10^{9} \mathrm{pfu}\right)$ into the myocardium via the right coronary artery four weeks after left anterior descending coronary artery (LAD) ligation in pigs, and detected the expression level of HGF by ELISA three weeks later. The results showed that the expression level of HGF in the experimental group increased to nearly 18 times that of the control group (109.3 $\pm 7.8 \mathrm{vs} 6.2 \pm 2.6)$, and the LVEF value increased by nearly $45 \%$ (43.9 \pm 4.3 vs 30.4 \pm 2.8$)$. Similarly, Funatsu et al. [38] injected 125 microg of plasmid encoding human HGF (hHGF) into the peri-infarct regions of canines four weeks after LAD ligation, and the expression of hHGF was specifically detected by ELISA after four weeks (endogenous HGF could not be detected). The results showed that hHGF expression in the HGF group was $4.7 \pm 1.7 \mathrm{ng} / \mathrm{g}$, while no hHGF protein expression was found in the control group, and the number of capillaries in the ischaemic area of the HGF group also increased to $140 \%$ of that in the normal area. Therefore, both plasmids and adenoviruses as vectors can effectively improve the expression of HGF. In addition, studies have shown that local application of plasmid HGF or Ad5-HGF is reliable in terms of safety [39]. As illustrated by the above points, plasmids and adenoviruses are ideal vectors for gene therapy. Our analysis showed that intracoronary Ad5-HGF gene transfer and intramyocardial plasmid HGF injection had similar effects on cardiac pump function at conventional doses, and both treatments could bring significant improvement in LVEF (12.63 \pm 3.2 and 9.4 $\pm 1.09 ; P=0.06)$. Injectable hydrogel is a promising synthetic biomaterial, with advantages such as mild gelation and cardiac-compatible properties $[40,41]$. Recent studies have shown that the injection of hydrogel in ischaemic areas after MI could promote cardiac repair and improve cardiac function [42]. Hydrogels can also encapsulate therapeutic drugs and deliver them to target areas to achieve sustained therapeutic effects [43]. Steele et al. [44] encapsulated two cytokines, dimeric fragment of HGF and engineered stromal cell-derived factor 1a, in hydrogels and delivered them to the peri-infarct regions, and found that the release time of the cytokines was significantly prolonged and the therapeutic effects were enhanced when the cytokines were encapsulated in hydrogels. These unique advantages of hydrogels potentially make them a more attractive method of exogenous administration. 
All of the studies included in this meta-analysis adopted local administration. The traditional route of local administration is either intracoronary delivery of therapeutic drugs through a catheter or intramyocardial injection through thoracotomy, which can be used locally in coronary artery bypass grafting [45]. Our analysis showed that intramyocardial injection of plasmid HGF had a stronger angiogenic capacity than intramyocardial injection of Ad5-HGF and HGF in hydrogel (Pख0.00001). Recently, Shi et al. [46] designed phase-transition microneedles coated with adenoassociated virus (AAV), which achieved uniform distribution of AAV delivery and were superior to direct muscular injection. This new delivery system may further optimise the efficacy of intramuscular injection. The advantage of local administration is that it effectively avoids the accumulation of drugs in other tissues and makes the concentration of drugs in the heart reach its peak. The disadvantage is that it limits the convenience and repeatability of its application. In contrast, systemic administration is more convenient, but it is necessary to find and apply heartspecific vectors to reduce the distribution of drugs in other tissues and organs.

This meta-analysis had certain strengths and limitations. First of all, this is the first meta-analysis pooling data from preclinical large animal studies, which provides strong evidence for the feasibility of HGF therapy in the treatment of MI. A second strength was that we analysed the therapeutic effects and characteristics of different vectors and delivery routes, and introduced a new intramuscular delivery system, providing a methodological basis for HGF gene therapy and other drug gene therapy. In terms of limitations, some studies did not provide relevant statistical data (three without LVEF data, four without capillary density data), which may partially affect the accuracy of the results. Secondly, most studies only used western blot to qualitatively analyse the expression difference of HGF between the experimental group and the control group without quantifying HGF expression. Therefore, we were unable to compare the differences in the expression of HGF between studies. In addition, there was some methodological heterogeneity in the included studies; however, they all observed the effects of HGF on cardiac function and angiogenesis in the chronic phase of $\mathrm{Ml}$, so we relaxed this aspect of our inclusion criteria and conducted some valid subgroup analyses to address the issue.

\section{Conclusion}

The safety of local HGF application has been preliminarily confirmed by previous Phase I clinical studies, which should be further verified by multicentre studies with more rigorous experimental design and longer follow-up times. Based on the current evidence, we demonstrated that HGF therapy after $\mathrm{Ml}$ could promote angiogenesis and improve cardiac function, and that intramyocardial injection of plasmid vector and intracoronary Ad5 vector transfer are effective means to achieve these effects. Although differences exist between humans and pigs, our study provides reliable evidence for clinical transformation of HGF therapy. In addition, HGF can combine with other therapeutic factors to have a synergistic effect. For example, a stronger therapeutic effect may be achieved through combined application of HGF with bone marrow mesenchymal stem cells, VEGF, and other therapeutic factors, although this needs to be confirmed by further preclinical and clinical trials.

\section{Declaration}

\section{Ethics approval and consent to participate}

Not applicable.

\section{Consent for publication}

Not applicable.

\section{Availability of data and materials}

The datasets generated and analyzed during the current study are available from the corresponding author on reasonable request.

\section{Competing interests}

The authors declare that they have no competing interests.

\section{Funding}

This work was supported by the National Natural Science Foundation of China (No. 81770361).

\section{Author contributions}

Chong Du designed and wrote the manuscript. Xiao-Wen Chen and Ze-Mu Wang collected the data and participated in the design. Hao-Yu Meng, Ya-Fei Li and Tian-Wen Wei conducted the analysis and developed the Figs. Lian-Sheng Wang (corresponding author) supervised and performed manuscript editing. All authors approved the final version of the manuscript.

\section{Acknowledgements}

None. 


\section{Abbreviations}

IHD: Ischemic Heart Disease; HGF: hepatocyte growth factor; VEGF: Vascular endothelial growth factor; MI: myocardial infarction; LVEF: left ventricular ejection fraction; HF: heart failure; MD: mean difference; Cl: confidence interval; Ad5-HGF: adenovirus5-mediated HGF; LAD: left anterior descending coronary artery; hHGF: human HGF; AAV: adeno-associated virus

\section{References}

1. Butchart A, Mikton C, Dahlberg LL, Krug EG. Global status report on violence prevention 2014. Inj Prev 2015, 21 (3):213.

2. Ongstad EL, Gourdie RG. Can heart function lost to disease be regenerated by therapeutic targeting of cardiac scar tissue? Semin Cell Dev Biol 2016, 58:41-54.

3. Bai L, Shin S, Burnett RT, Kwong JC, Hystad P, van Donkelaar A, Goldberg MS, Lavigne E, Copes R, Martin RV et al. Exposure to ambient air pollution and the incidence of congestive heart failure and acute myocardial infarction: A population-based study of 5.1 million Canadian adults living in Ontario. Environ Int 2019, 132:105004.

4. Lupu IE, De Val S, Smart N. Coronary vessel formation in development and disease: mechanisms and insights for therapy. Nat Rev Cardiol 2020.

5. Castelvecchio S, Pappalardo OA, Menicanti L. Myocardial reconstruction in ischaemic cardiomyopathy. Eur J Cardiothorac Surg 2019, 55(Suppl 1):i49-i56.

6. Du C, Fan Y, Li YF, Wei TW, Wang LS. Research progress on myocardial regeneration: what is new? Chin Med J (Engl) 2020(6):716-23.

7. Musumeci F, Amarelli C, Montalto A. [Heart transplantation: from the pioneering era to future prospects]. G Ital Cardiol (Rome) 2018, 19(11):606-10.

8. Yao J, Ke J, Zhou Z, Tan G, Yin Y, Liu M, Chen J, Wu W. Combination of HGF and IGF-1 promotes connexin 43 expression and improves ventricular arrhythmia after myocardial infarction through activating the MAPK/ERK and MAPK/p38 signaling pathways in a rat model. Cardiovasc Diagn Ther 2019, 9(4):346-54.

9. Madonna R, Cevik C, Nasser M, De Caterina R. Hepatocyte growth factor: molecular biomarker and player in cardioprotection and cardiovascular regeneration. Thromb Haemost 2012, 107(4):656-61.

10. Makarevich PI, Dergilev KV, Tsokolaeva ZI, Boldyreva MA, Shevchenko EK, Gluhanyuk EV, Gallinger JO, Menshikov MY, Parfyonova YV. Angiogenic and pleiotropic effects of VEGF165 and HGF combined gene therapy in a rat model of myocardial infarction. PLoS One 2018, 13(5):e0197566.

11. Rong SL, Wang XL, Wang YC, Wu H, Zhou XD, Wang ZK, Wang YC, Xue CS, Li B, Gao DL. Anti-inflammatory activities of hepatocyte growth factor in post-ischemic heart failure. Acta Pharmacol Sin 2018, 39(10):1613-21.

12. Koudstaal S, Bastings MM, Feyen DA, Waring CD, van Slochteren FJ, Dankers PY, Torella D, Sluijter JP, Nadal-Ginard B, Doevendans PA et al. Sustained delivery of insulin-like growth factor-1/hepatocyte growth factor stimulates endogenous cardiac repair in the chronic infarcted pig heart. J Cardiovasc Transl Res 2014, 7(2):232-41.

13. Sonnenberg SB, Rane AA, Liu CJ, Rao N, Agmon G, Suarez S, Wang R, Munoz A, Bajaj V, Zhang S et al. Delivery of an engineered HGF fragment in an extracellular matrix-derived hydrogel prevents negative LV remodeling post-myocardial infarction. Biomaterials 2015, 45:56-63.

14. Carlsson M, Osman NF, Ursell PC, Martin AJ, Saeed M. Quantitative MR measurements of regional and global left ventricular function and strain after intramyocardial transfer of VM202 into infarcted swine myocardium. Am J Physiol Heart Circ Physiol 2008, 295(2):H522-32.

15. Wang W, Yang ZJ, Ma DC, Wang LS, Xu SL, Zhang YR, Cao KJ, Zhang FM, Ma WZ. Induction of collateral artery growth and improvement of post-infarct heart function by hepatocyte growth factor gene transfer. Acta Pharmacol Sin 2006, 27(5):555-60.

16. Yang ZJ, Chen B, Sheng Z, Zhang DG, Jia EZ, Wang W, Ma DC, Zhu TB, Wang LS, Li CJ et al. Improvement of heart function in postinfarct heart failure swine models after hepatocyte growth factor gene transfer: comparison of low-, medium- and high-dose groups. Mol Biol Rep 2010, 37(4):2075-81.

17. Saeed M, Martin A, Ursell P, Do L, Bucknor M, Higgins CB, Saloner D. MR assessment of myocardial perfusion, viability, and function after intramyocardial transfer of VM202, a new plasmid human hepatocyte growth factor in ischemic swine myocardium. Radiology 2008, 249(1):107-18.

18. Cho KR, Choi JS, Hahn W, Kim DS, Park JS, Lee DS, Kim KB. Therapeutic angiogenesis using naked DNA expressing two isoforms of the hepatocyte growth factor in a porcine acute myocardial infarction model. Eur J Cardiothorac Surg 2008, 34(4):857-63.

19. ZHANG Sheng, YANG Zhi-jian, WANG Wei, MA Dong-chao, MA Wen-zhu, CAO Ke-jiang. Effect on post-infarct heart function and apoptosis of cardiocyte with Ad5-HGF transference in swine. ACTA UNIVERSITATIS MEDICINALIS NANJING(Natural Science) 2008, 28(8):959-63.

20. Saeed M, Saloner D, Do L, Wilson M, Martin A. Cardiovascular magnetic resonance imaging in delivering and evaluating the efficacy of hepatocyte growth factor gene in chronic infarct scar. Cardiovasc Revasc Med 2011, 12(2):111-22. 
21. Chen B, Tao Z, Zhao Y, Chen H, Yong Y, Liu X, Wang H, Wu Z, Yang Z, Yuan L. Catheter-based intramyocardial delivery (NavX) of adenovirus achieves safe and accurate gene transfer in pigs. PLoS One 2013, 8(1):e53007.

22. Fattah C, Nather K, McCarroll CS, Hortigon-Vinagre MP, Zamora V, Flores-Munoz M, McArthur L, Zentilin L, Giacca M, Touyz RM et al. Gene Therapy With Angiotensin-(1-9) Preserves Left Ventricular Systolic Function After Myocardial Infarction. J Am Coll Cardio/ 2016, 68(24):265266.

23. Zhu H, Jiang X, Li X, Hu M, Wan W, Wen Y, He Y, Zheng X. Intramyocardial delivery of VEGF165 via a novel biodegradable hydrogel induces angiogenesis and improves cardiac function after rat myocardial infarction. Heart Vessels 2016, 31(6):963-75.

24. Rao Z, Shen D, Chen J, Jin L, Wu X, Chen M, Li L, Chu M, Lin J. Basic Fibroblast Growth Factor Attenuates Injury in Myocardial Infarction by Enhancing Hypoxia-Inducible Factor-1 Alpha Accumulation. Front Pharmacol 2020, 11:1193.

25. Fu Y, Li J, Wu S, Wang H. Electroacupuncture pretreatment promotes angiogenesis via hypoxia-inducible factor 1alpha and vascular endothelial growth factor in a rat model of chronic myocardial ischemia. Acupunct Med 2020:964528420938378.

26. Wang C, Zhang B, Lin Y, Dong Y. Effects of Adenovirus-mediated VEGF165 Gene Therapy on Myocardial Infarction. Ann Clin Lab Sci 2018, 48(2):208-15.

27. Gallo S, Sala V, Gatti S, Crepaldi T. HGF/Met Axis in Heart Function and Cardioprotection. Biomedicines 2014, 2(4):247-62.

28. Narmada BC, Chia SM, Tucker-Kellogg L, Yu H. HGF regulates the activation of TGF-beta1 in rat hepatocytes and hepatic stellate cells. $J$ Cell Physiol 2013, 228(2):393-401.

29. Jiang ZZ, Xia GY, Zhang Y, Dong L, He BZ, Sun JG. Attenuation of hepatic fibrosis through ultrasound-microbubble-mediated HGF gene transfer in rats. Clin Imaging 2013, 37(1):104-10.

30. Sanada F, Taniyama Y, Kanbara Y, Otsu R, Ikeda-Iwabu Y, Carracedo M, Rakugi H, Morishita R. Gene therapy in peripheral artery disease. Expert Opin Biol Ther 2015, 15(3):381-90.

31. Shimamura M, Nakagami H, Sanada F, Morishita R. Progress of Gene Therapy in Cardiovascular Disease. Hypertension 2020, 76(4):1038-44.

32. Gherardi E, Birchmeier W, Birchmeier C, Vande Woude G. Targeting MET in cancer: rationale and progress. Nat Rev Cancer 2012, $12(2): 89-103$.

33. Blumenschein GR, Jr., Mills GB, Gonzalez-Angulo AM. Targeting the hepatocyte growth factor-cMET axis in cancer therapy. J Clin Oncol 2012 , 30(26):3287-96.

34. Benkhoucha M, Molnarfi N, Dunand-Sauthier I, Merkler D, Schneiter G, Bruscoli S, Riccardi C, Tabata Y, Funakoshi H, Nakamura T et al. Hepatocyte growth factor limits autoimmune neuroinflammation via glucocorticoid-induced leucine zipper expression in dendritic cells. $J$ Immunol 2014, 193(6):2743-52.

35. Wang W, Wang MQ, Wang H, Gao W, Zhang Z, Zhao S, Xu HZ, Chen B, Zhu MX, Wu ZZ et al. Effects of Adenovirus-Mediated Hepatocyte Growth Factor Gene Therapy on Postinfarct Heart Function: Comparison of Single and Repeated Injections. Hum Gene Ther 2016, 27(8):643-51.

36. Meng H, Chen B, Tao Z, Xu Z, Wang L, Weizhu J, Hong Y, Liu X, Wang H, Wang L et al. Safety and Efficacy of Adenovirus Carrying Hepatocyte Growth Factor Gene by Percutaneous Endocardial Injection for Treating Post-infarct Heart Failure: A Phase Ila Clinical Trial. Curr Gene Ther 2018, 18(2):125-30.

37. Wang D, Tai PWL, Gao G. Adeno-associated virus vector as a platform for gene therapy delivery. Nat Rev Drug Discov 2019, 18(5):358-78.

38. Funatsu T, Sawa Y, Ohtake S, Takahashi T, Matsumiya G, Matsuura N, Nakamura T, Matsuda H. Therapeutic angiogenesis in the ischemic canine heart induced by myocardial injection of naked complementary DNA plasmid encoding hepatocyte growth factor. $J$ Thorac Cardiovasc Surg 2002, 124(6):1099-105.

39. Gu Y, Zhang J, Guo L, Cui S, Li X, Ding D, Kim JM, Ho SH, Hahn W, Kim S. A phase I clinical study of naked DNA expressing two isoforms of hepatocyte growth factor to treat patients with critical limb ischemia. J Gene Med 2011, 13(11):602-10.

40. Bar A, Cohen S. Inducing Endogenous Cardiac Regeneration: Can Biomaterials Connect the Dots? Front Bioeng Biotechnol $2020,8: 126$.

41. Firoozi S, Pahlavan S, Ghanian MH, Rabbani S, Tavakol S, Barekat M, Yakhkeshi S, Mahmoudi E, Soleymani M, Baharvand H. A Cell-Free SDKPConjugated Self-Assembling Peptide Hydrogel Sufficient for Improvement of Myocardial Infarction. Biomolecules 2020, 10(2).

42. Song Y, Zhang C, Zhang J, Sun N, Huang K, Li H, Wang Z, Huang K, Wang L. An injectable silk sericin hydrogel promotes cardiac functional recovery after ischemic myocardial infarction. Acta Biomater 2016, 41:210-23.

43. Wang LL, Chung JJ, Li EC, Uman S, Atluri P, Burdick JA. Injectable and protease-degradable hydrogel for siRNA sequestration and triggered delivery to the heart. $J$ Control Release 2018, 285:152-61.

44. Steele AN, Paulsen MJ, Wang H, Stapleton LM, Lucian HJ, Eskandari A, Hironaka CE, Farry JM, Baker SW, Thakore AD et al. Multi-phase catheter-injectable hydrogel enables dual-stage protein-engineered cytokine release to mitigate adverse left ventricular remodeling following myocardial infarction in a small animal model and a large animal model. Cytokine 2020, 127:154974.

45. Penny WF, Henry TD, Watkins MW, Patel AN, Hammond HK. Design of a Phase 3 trial of intracoronary administration of human adenovirus 5 encoding human adenylyl cyclase type 6 (RT-100) gene transfer in patients with heart failure with reduced left ventricular ejection fraction: The FLOURISH Clinical Trial. Am Heart J 2018, 201:111-6. 
46. Shi H, Xue T, Yang Y, Jiang C, Huang S, Yang Q, Lei D, You Z, Jin T, Wu F et al. Microneedle-mediated gene delivery for the treatment of ischemic myocardial disease. Sci Adv 2020, 6(25):eaaz3621.

\section{Tables}

Table 1. Methodological quality of the included studies

\begin{tabular}{|c|c|c|c|c|c|}
\hline Study & $\begin{array}{l}\text { randomized controlled } \\
\text { study }\end{array}$ & $\begin{array}{l}\text { Adequate } \\
\text { allocation }\end{array}$ & $\begin{array}{l}\text { Method of randomization } \\
\text { described }\end{array}$ & $\begin{array}{l}\text { Operator } \\
\text { blinded }\end{array}$ & $\begin{array}{l}\text { Analyst } \\
\text { blinded }\end{array}$ \\
\hline $\begin{array}{l}\text { Koudstaal et al. } 2014 \\
\text { [12] }\end{array}$ & Y & Y & $\mathrm{N}$ & $\mathrm{N}$ & $\mathrm{N}$ \\
\hline $\begin{array}{l}\text { Carlsson et al. } 2008 \\
\text { [14] }\end{array}$ & $\mathrm{Y}$ & Y & $\mathrm{N}$ & $\mathrm{N}$ & $\mathrm{N}$ \\
\hline WANG et al. 2006 [15] & Y & $\mathrm{Y}$ & $\mathrm{N}$ & $\mathrm{N}$ & $\mathrm{N}$ \\
\hline Yang et al. 2010 [16] & Y & Y & $\mathrm{N}$ & $\mathrm{N}$ & $\mathrm{N}$ \\
\hline Saeed et al. 2008 [17] & Y & Y & $\mathrm{N}$ & $\mathrm{N}$ & $\mathrm{N}$ \\
\hline Cho et al. 2008 [18] & Y & Y & $\mathrm{N}$ & $\mathrm{N}$ & $\mathrm{N}$ \\
\hline Zhang et al. 2008 [19] & Y & $\mathrm{N}$ & $\mathrm{N}$ & $\mathrm{N}$ & $\mathrm{N}$ \\
\hline Saeed et al. 2011 [20] & $\mathrm{Y}$ & Y & $\mathrm{N}$ & $\mathrm{N}$ & $\mathrm{N}$ \\
\hline Chen et al. 2013 [21] & Y & Y & $\mathrm{N}$ & $\mathrm{N}$ & $\mathrm{N}$ \\
\hline
\end{tabular}

Note: The study conducted by Zhang et al. [19] was published on the China National Knowledge Information database. Y, yes; N, no

Table 2. Summary of characteristics of the included studies

\begin{tabular}{|c|c|c|c|c|c|c|c|c|c|c|}
\hline $\begin{array}{l}\text { Author, } \\
\text { year }\end{array}$ & pig breed & Sex & $\begin{array}{l}\text { Weight } \\
\text { (kg) }\end{array}$ & $\mathrm{n}_{\mathrm{t}} / \mathrm{n}_{\mathrm{c}}$ & intervention & dose & $\begin{array}{l}\text { administration } \\
\text { method }\end{array}$ & $\begin{array}{l}\text { Timing } \\
\text { of } \\
\text { therapy }\end{array}$ & $\begin{array}{l}\text { Control } \\
\text { factors }\end{array}$ & $\begin{array}{l}\text { follow- } \\
\text { up }\end{array}$ \\
\hline $\begin{array}{l}\text { WANG et } \\
\text { al. } 2006\end{array}$ & $\begin{array}{l}\text { Suzhong } \\
\text { swine }\end{array}$ & male & $30 \pm 5$ & $6 / 6$ & Ad5-HGF & $4 \times 10^{9} \mathrm{pfu}$ & $\begin{array}{l}\text { Intracoronary } \\
\text { gene transfer }\end{array}$ & $\begin{array}{l}4 \\
\text { weeks } \\
\text { post Ml }\end{array}$ & null-Ad5 & $\begin{array}{l}7 \\
\text { weeks }\end{array}$ \\
\hline $\begin{array}{l}\text { Saeed et } \\
\text { al. } 2008\end{array}$ & $\begin{array}{l}\text { not } \\
\text { mentioned }\end{array}$ & Female/male & $30 \pm 4$ & $8 / 8$ & $\begin{array}{l}\text { plasmid } \\
\text { pCK-HGF- } \\
\text { X7 }\end{array}$ & $2 \mathrm{mg}$ & $\begin{array}{l}\text { intramyocardial } \\
\text { injections }\end{array}$ & $\begin{array}{l}3 \text { hours } \\
\text { post MI }\end{array}$ & saline & $\begin{array}{l}50 \\
\text { days } \pm 3\end{array}$ \\
\hline $\begin{array}{l}\text { Carlsson } \\
\text { et al. } \\
2008\end{array}$ & $\begin{array}{l}\text { not } \\
\text { mentioned }\end{array}$ & Female/male & $30-40$ & $8 / 8$ & $\begin{array}{l}\text { plasmid } \\
\text { pCK-HGF- } \\
\text { X7 }\end{array}$ & $2 \mathrm{mg}$ & $\begin{array}{l}\text { intramyocardial } \\
\text { injections }\end{array}$ & $\begin{array}{l}3 \text { hours } \\
\text { post Ml }\end{array}$ & saline & $\begin{array}{l}50 \\
\text { days } \pm 3\end{array}$ \\
\hline $\begin{array}{l}\text { Koudstaal } \\
\text { et al. } \\
2014\end{array}$ & $\begin{array}{l}\text { Dalland } \\
\text { landrace } \\
\text { pigs }\end{array}$ & female & $\sim 70$ & $5 / 5$ & $\begin{array}{l}\text { HGF in } \\
\text { hydrogel }\end{array}$ & $1 \mathrm{mg}$ & $\begin{array}{l}\text { intramyocardial } \\
\text { injections }\end{array}$ & $\begin{array}{l}4 \\
\text { weeks } \\
\text { post MI }\end{array}$ & hydrogel & $\begin{array}{l}8 \\
\text { weeks }\end{array}$ \\
\hline $\begin{array}{l}\text { Cho et al. } \\
2008\end{array}$ & $\begin{array}{l}\text { Yorkshire } \\
\text { swine }\end{array}$ & male & $31.5 \pm 2.1$ & $7 / 7$ & $\begin{array}{l}\text { plasmid } \\
\text { pCK-HGF- } \\
\text { X7 }\end{array}$ & $1 \mathrm{mg}$ & $\begin{array}{l}\text { intramyocardial } \\
\text { injection }\end{array}$ & $\begin{array}{l}4 \\
\text { weeks } \\
\text { post MI }\end{array}$ & $\begin{array}{l}\text { pCK- } \\
\text { LacZ }\end{array}$ & $\begin{array}{l}8 \\
\text { weeks }\end{array}$ \\
\hline $\begin{array}{l}\text { Chen et } \\
\text { al. } 2013\end{array}$ & mini-pigs & male & $36 \pm 3.4$ & $6 / 6$ & Ad5-HGF & $\begin{array}{l}1 \times 10^{10} \\
\text { genome } \\
\text { copies }\end{array}$ & $\begin{array}{l}\text { Intramyocardial } \\
\text { Delivery }\end{array}$ & $\begin{array}{l}4 \\
\text { weeks } \\
\text { post MI }\end{array}$ & saline & $\begin{array}{l}8 \\
\text { weeks }\end{array}$ \\
\hline $\begin{array}{l}\text { Yang et } \\
\text { al. } 2010\end{array}$ & $\begin{array}{l}\text { not } \\
\text { mentioned }\end{array}$ & male & $23 \pm 3$ & $6 / 6$ & Ad5-HGF & $5 \times 10^{9} \mathrm{Pfu}$ & $\begin{array}{l}\text { Intracoronary } \\
\text { gene transfer }\end{array}$ & $\begin{array}{l}4 \\
\text { weeks } \\
\text { post Ml }\end{array}$ & null-Ad5 & $\begin{array}{l}7 \\
\text { weeks }\end{array}$ \\
\hline $\begin{array}{l}\text { Saeed et } \\
\text { al. } 2011\end{array}$ & $\begin{array}{l}\text { not } \\
\text { mentioned }\end{array}$ & Female/male & $30-32$ & $6 / 6$ & $\begin{array}{l}\text { plasmid } \\
\text { pCK-HGF- } \\
\text { X7 }\end{array}$ & $\begin{array}{l}3.96 \times 10^{11} \\
\text { viral } \\
\text { copies }\end{array}$ & $\begin{array}{l}\text { intramyocardial } \\
\text { injection }\end{array}$ & $\begin{array}{l}5 \\
\text { weeks } \\
\text { post MI }\end{array}$ & $\begin{array}{l}\text { pCK- } \\
\text { LacZ }\end{array}$ & $\begin{array}{l}10 \\
\text { weeks }\end{array}$ \\
\hline $\begin{array}{l}\text { Zhang et } \\
\text { al. } 2008\end{array}$ & mini-pigs & Female/male & $26 \pm 3$ & $5 / 6$ & Ad5-HGF & $5 \times 10^{9} \mathrm{Pfu}$ & $\begin{array}{l}\text { Intracoronary } \\
\text { gene transfer }\end{array}$ & $\begin{array}{l}4 \\
\text { weeks } \\
\text { post Ml }\end{array}$ & null-Ad5 & $\begin{array}{l}7 \\
\text { weeks }\end{array}$ \\
\hline
\end{tabular}

$n$, number of animals $\left(n_{c}\right.$, control; $n_{t}$, treated); HGF, Hepatocyte growth factor; Ad5-HGF, adenovirus-mediated HGF 
Figures
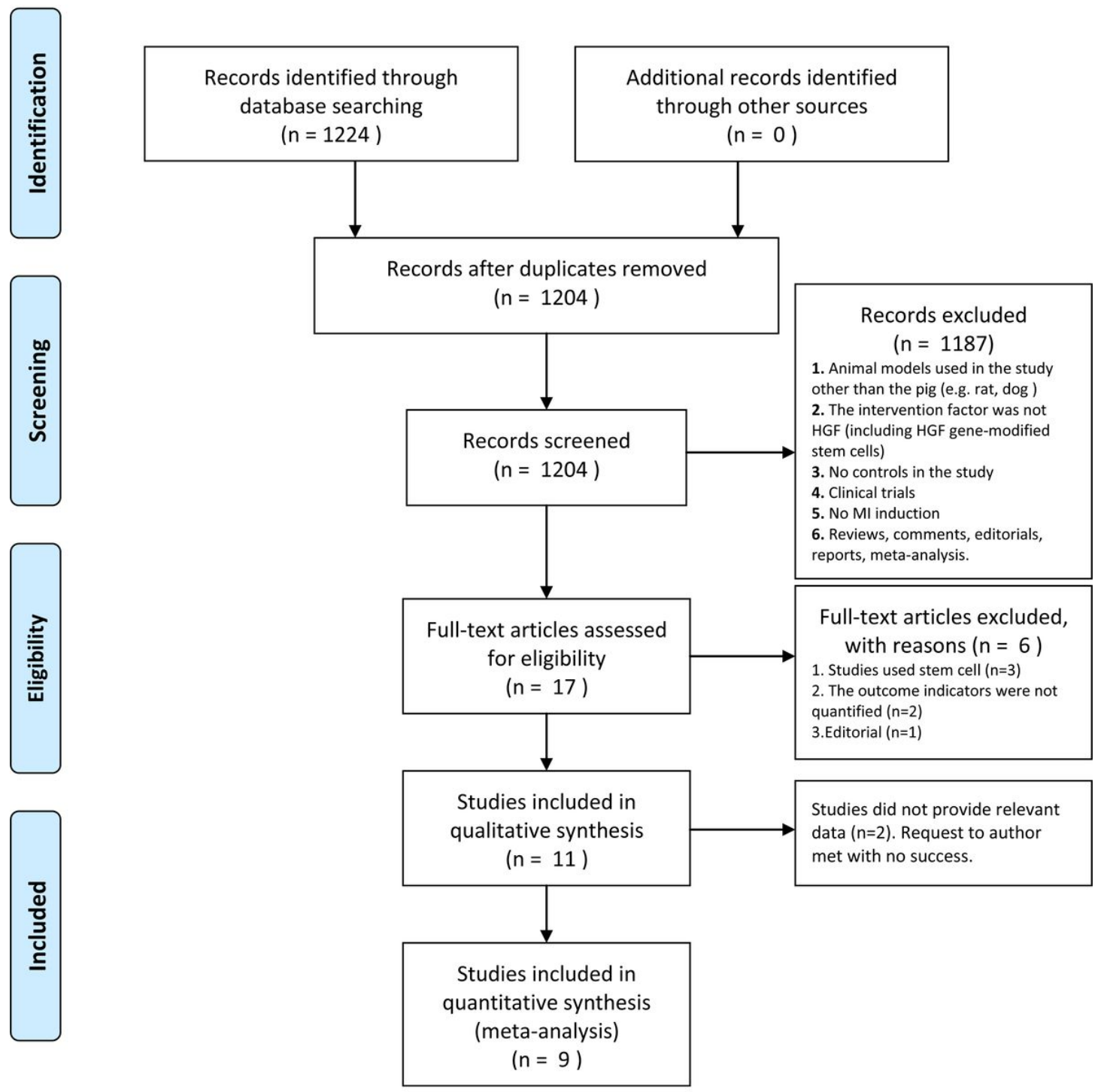

Figure 1

The flow diagram of the study selection.

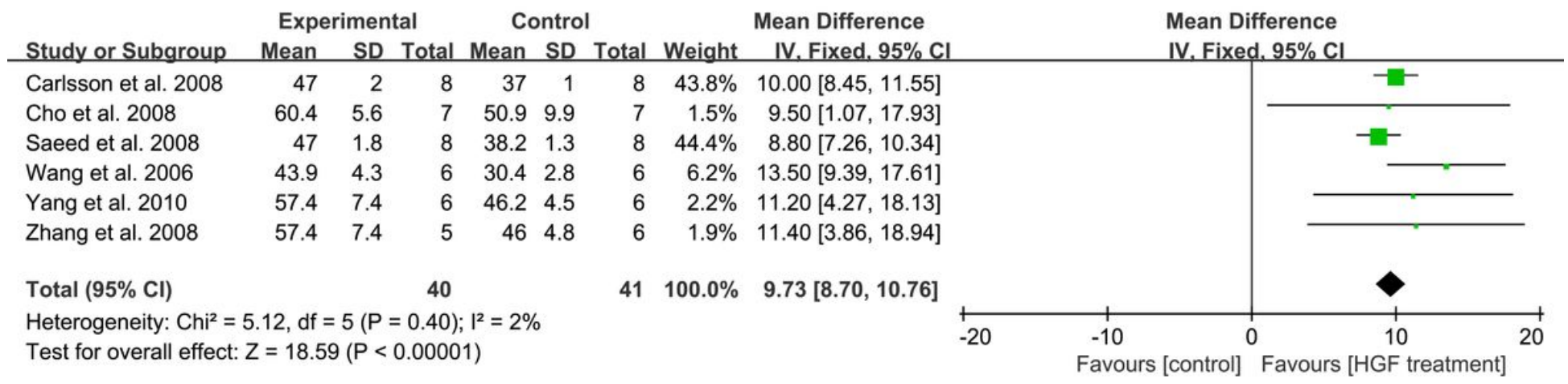

Figure 2

Forest plot showing the impact of HGF therapy on LVEF. LVEF: left ventricular ejection fraction; 


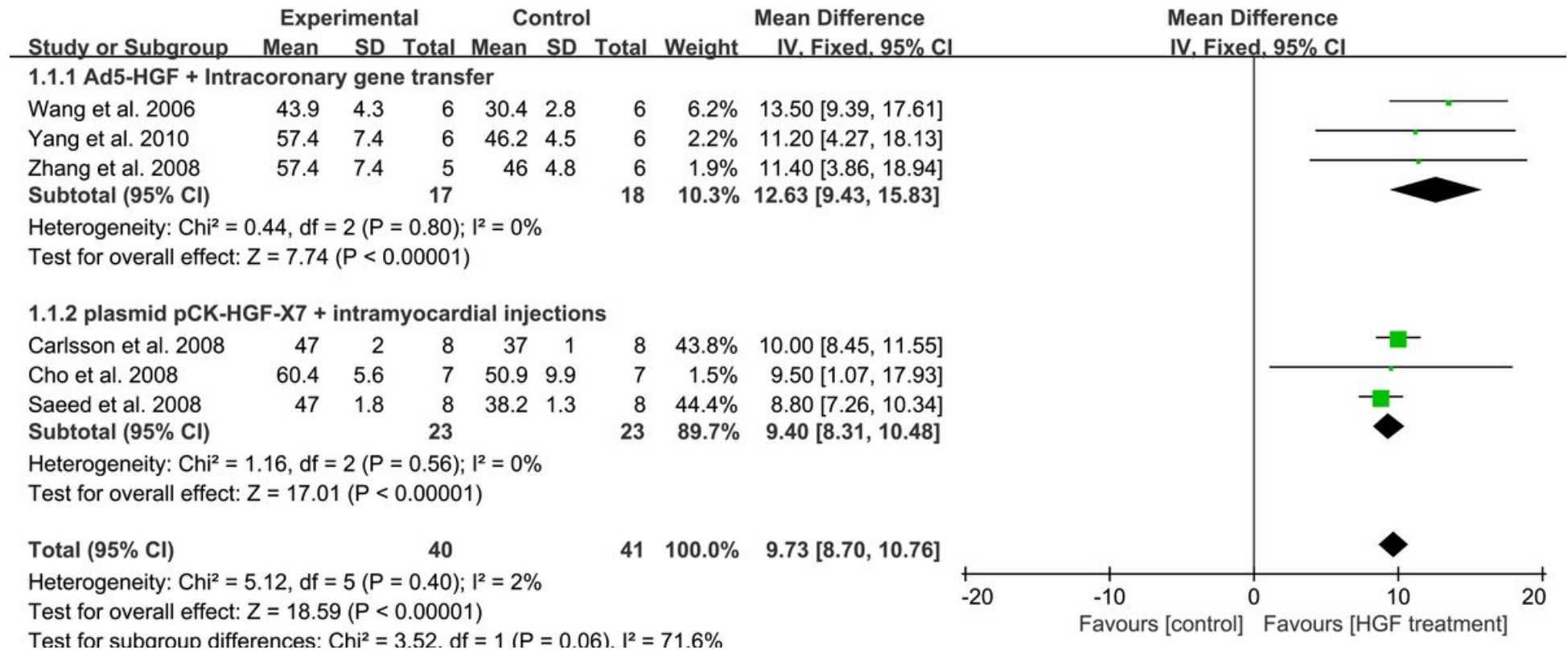

\section{Figure 3}

Subgroup analysis based on intracoronary Ad5-HGF gene transfer and intramyocardial plasmid HGF injection. Ad5-HGF: adenovirus5-mediated hepatocyte growth factor.

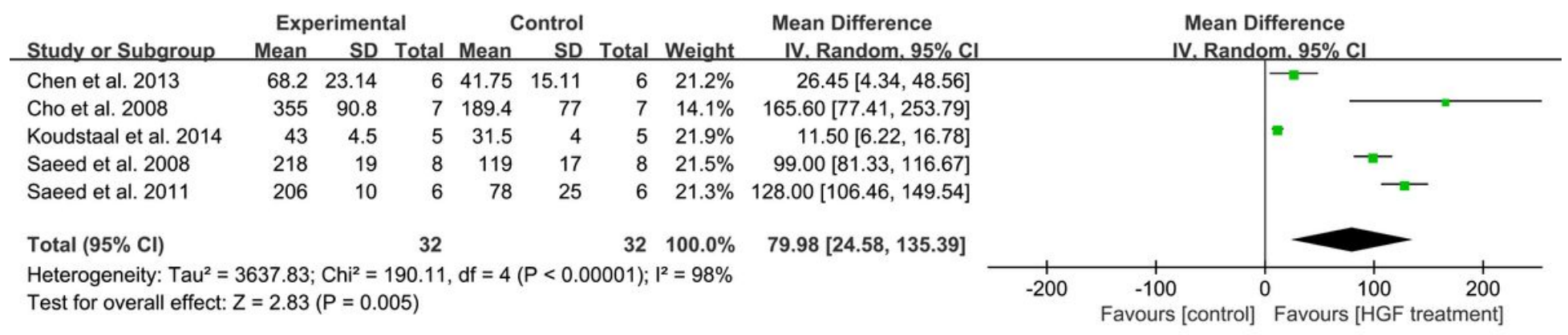

Figure 4

Forest plot showing the impact of HGF therapy on angiogenesis. Angiogenesis is measured by capillary density (capillaries/mm2).

\begin{tabular}{lrrrrrrrr} 
& \multicolumn{2}{c}{ Experimental } & \multicolumn{3}{c}{ Control } & & Mean Difference \\
Study or Subgroup & Mean & SD & Total & Mean & SD & Total & Weight & IV. Random. 95\% Cl \\
\hline 2.1.1 plasmid pCK-HGF-X7 & & & & & & & \\
Cho et al. 2008 & 355 & 90.8 & 7 & 189.4 & 77 & 7 & $14.1 \%$ & $165.60[77.41,253.79]$ \\
Saeed et al. 2008 & 218 & 19 & 8 & 119 & 17 & 8 & $21.5 \%$ & $99.00[81.33,116.67]$ \\
Saeed et al. 2011 & 206 & 10 & 6 & 78 & 25 & 6 & $21.3 \%$ & $128.00[106.46,149.54]$ \\
Subtotal (95\% Cl) & & & 21 & & & 21 & $\mathbf{5 6 . 9 \%}$ & $\mathbf{1 1 7 . 3 4}[89.52,145.16]$
\end{tabular}

$56.9 \% \quad 117.34[89.52,145.16]$

Heterogeneity: $\mathrm{Tau}^{2}=340.32 ; \mathrm{Chi}^{2}=5.62, \mathrm{df}=2(\mathrm{P}=0.06) ; \mathrm{I}^{2}=64 \%$

Test for overall effect: $Z=8.27(P<0.00001)$

\subsubsection{Ad5-HGF}

Chen et al. 2013

Subtotal $(95 \% \mathrm{Cl})$

$68.2 \quad 23.14$

$6 \quad 41.75 \quad 15.11$

$6 \quad 21.2 \%$

$6 \quad 21.2 \%$

$26.45[4.34,48.56]$

$26.45[4.34,48.56]$

Heterogeneity: Not applicable

Test for overall effect: $Z=2.34(P=0.02)$

2.1.3 HGF in hydrogel

$\begin{array}{lllllllrr}\text { Carlsson et al. 2008 } & 43 & 4.5 & 5 & 31.5 & 4 & 5 & 21.9 \% & 11.50[6.22,16.78] \\ \text { Subtotal }(95 \% \mathrm{CI}) & & & \mathbf{5} & & & \mathbf{5} & \mathbf{2 1 . 9 \%} & \mathbf{1 1 . 5 0}[6.22,16.78]\end{array}$

Heterogeneity: Not applicable

Test for overall effect: $Z=4.27(P<0.0001)$

Total $(95 \% \mathrm{Cl})$

32

$32 \quad 100.0 \%$

Heterogeneity: $\mathrm{Tau}^{2}=3637.83 ; \mathrm{Chi}^{2}=190.11, \mathrm{df}=4(\mathrm{P}<0.00001) ; \mathrm{I}^{2}=98 \%$

Test for overall effect: $Z=2.83(P=0.005)$

Test for subaroun differences: $\mathrm{Chi}^{2}=54.62 . \mathrm{df}=2(\mathrm{P}<0.00001) . \mathrm{I}^{2}=96.3 \%$
$79.98[24.58,135.39]$

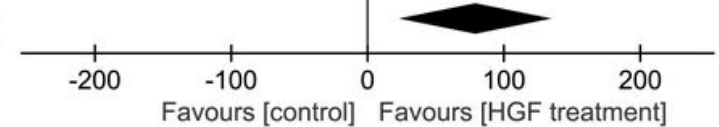


Figure 5

Subgroup analysis based on different vectors under the same route of administration (intramyocardial injection). Ad5-HGF: adenovirus5-mediated hepatocyte growth factor.

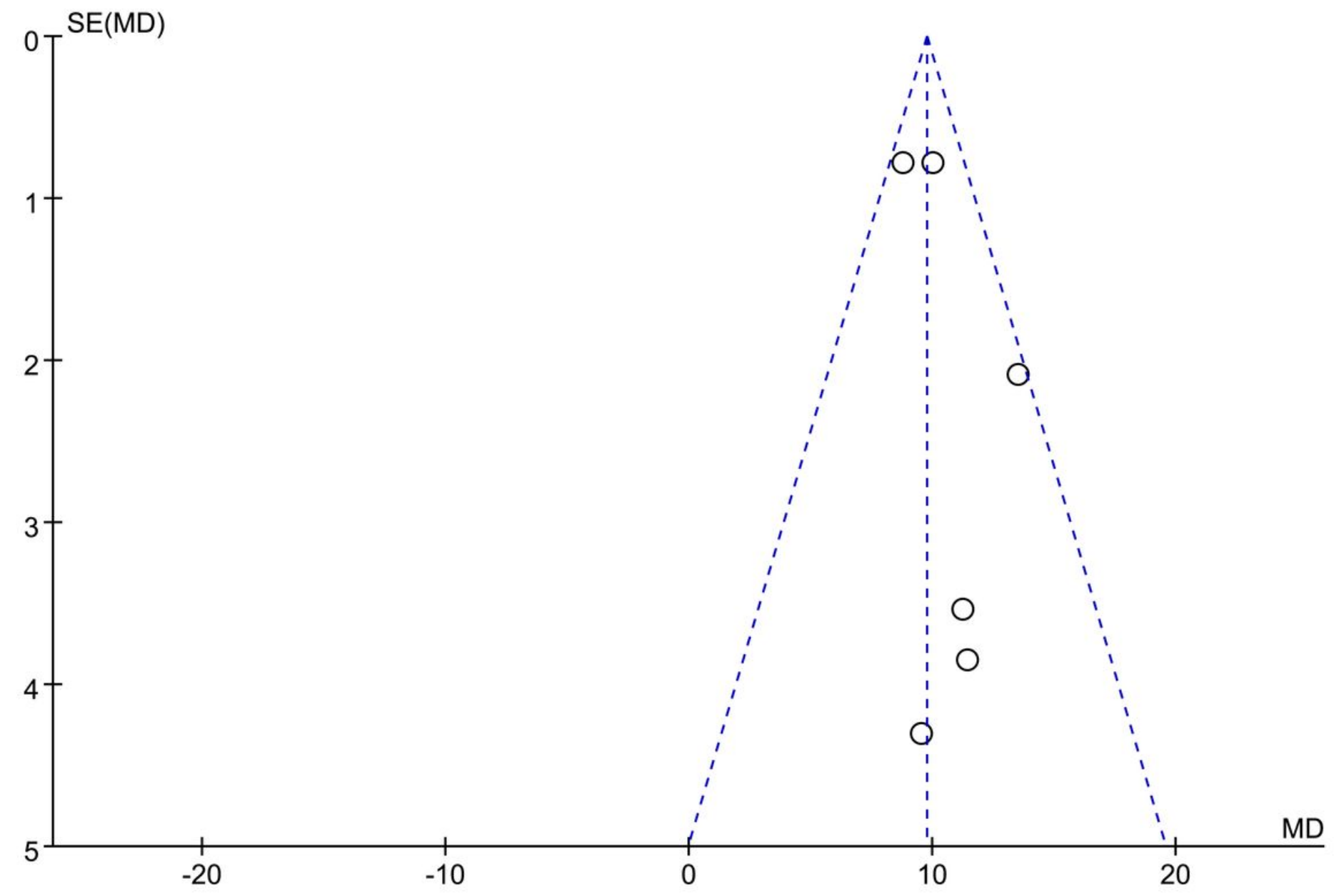

Figure 6

Publication biases. A funnel plot illustrating publication biases for included studies comparing LVEF between the HGF group and the control group.

\section{Supplementary Files}

This is a list of supplementary files associated with this preprint. Click to download.

- PRISMA2009checklist.doc 